\title{
KONSERVASI ENERGI BERBASIS RENEWABLE ENERGY TECHNOLOGY DENGAN PEMANFAATAN TEKNOLOGI MICROBIAL
}

\author{
Ganjar Samudro \\ Program Studi Teknik Lingkungan, Fakultas Teknik, Universitas Diponegoro \\ Jl. Prof. H. Soedarto, S.H. Tembalang-Semarang, Kode Pos 50275 \\ Telp : (024) 76480678, Fax : (024) 76918157 \\ e-mail: ganjarsamudro@gmail.com, ganjarsamudro@undip.ac.id
}

\begin{abstract}
ABSTRAK
Penggunaan energi yang besar meningkatkan emisi $\mathrm{CO}_{2}$ yang terlepas ke atmosfer. Upaya konservasi energi terus dilakukan dalam rangka meningkatkan kebutuhan energi. Bentuk konservasi energi berbasis renewable energy technology dengan pemanfaatan teknologi microbial merupakan bentuk ideal back to nature dan lebih ramah lingkungan untuk masa depan lingkungan yang lebih baik. Penelitian-penelitian berbasis teknologi microbial dengan basis modifikasi teknologi konvensional dengan advanced menjadi pilihan terbaik dalam capture energi besar, kebutuhan energi nol, revenue listrik tinggi dan biaya operasional yang rendah. Pilihan inovasi teknologi ini membuka wacana pengembangan inovasi teknologi microbial lainnya dan memberikan kontribusi pengurangan emisi $\mathrm{CO}_{2}$ dari suatu proses. Hasilhasil penelitian terbaru dengan reaktor MFCs sebagai salah satu teknologi microbial didapatkan kecenderungan positif dalam pemanfaatannya dalam skala yang lebih besar dan aplikatif.
\end{abstract}

Kata kunci: energi, emisi $\mathrm{CO}_{2}$, teknologi microbial, MFCs

\begin{abstract}
The utilization of high energy will increase $\mathrm{CO}_{2}$ emission releasing to the atmospheric. The effort of energy conservation is continuosly conducted to increase of energy demand. The form of energy conservation based on renewable energy technology by the utilization of microbial technology is the ideal of back to nature and more eco-friendly for the better future of environment. The researches of microbial technology basis by modification between conventional and advanced will be the best choice in highly energy capture, zero energy demand, highly electricity revenue dan low cost of maintenance. The choice of this technology innovation open the other microbial technology development and giving a contribution of $\mathrm{CO}_{2}$ emission reduction in a process. The results of the newest research by MFCs reactor as the one of microbial technology is positive trends in the high scale of utilization and applicative.
\end{abstract}

Keywords: energy, $\mathrm{CO}_{2}$ emmision, microbial technology, MFCs

\section{PENDAHULUAN}

Peningkatan kebutuhan energi
meningkat seiring dengan peningkatan
jumlah penduduk. Secara global, suplai
energi semakin menipis dikarenakan belum
banyak eksplorasi-eksplorasi baru dari
sumber energi tidak terbarukan.
Peningkatan jumlah penduduk dan
penipisan suplai energi memiliki kecenderungan berbanding terbalik, maka diperlukan upaya-upaya solutif dalam menangani keterbatasan energi.

Penggunaan energi dari sumber energi tidak terbarukan menyebabkan peningkatan emisi gas buang baik dari kegiatan domestik maupun non-domestik, sehingga meningkatkan kontribusi pada pemanasan global atau global warming dan akibatakibat yang ditimbulkannya. Jika kita memperoleh energi dari sumber-sumber energi tidak terbarukan menggunakan teknologi konvensional, kita akan merilis tambahan $\mathrm{CO}_{2}$, memperburuk kerusakan lingkungan, dan mempercepat perubahan iklim global (Logan, 2008). Pemenuhan energi listrik didapatkan dari penggunaan bahan bakar minyak melalui generator/turbin listrik. Kondisi ini dapat menimbulkan dampak lingkungan khususnya pencemaran udara dikarenakan 
adanya emisi $\mathrm{CO}_{2}$ dari pembakaran bahan bakar minyak (Samudro dkk, 2014).

Akhir-akhir ini, pengembangan teknologi konservasi energi telah banyak ditingkatkan untuk mencapai produk teknologi yang ramah lingkungan. Pengembangan energi dominan terjadi pada non-bioteknologi, walaupun secara kenyataan, terdapat banyak usaha-usaha pengembangan bio-teknologi sebagai dasar teknologi konservasi energi, namun jumlahnya masih sangat sedikit. Hal inilah yang mengindikasikan melambatnya pengembangan teknologi konservasi energi berbasis renewable energy technology. Pengembangan teknologi konservasi energi ini perlu dikembangkan secara optimal, karena dampak yang muncul lebih ringan pada beban lingkungannya dibandingkan teknologi konservasi energi berbasis unrenewable energy technology. Penggunaan teknologi berbasis microbial menjadi solusi terbaik saat ini, dikarenakan pemanfaatannya tidak menimbulkan dampak lingkungan yang buruk, melainkan memberikan kontribusi adaptasi dan mitigasi (Samudro dkk, 2014).

\section{ISU-ISU ENERGI TERKINI}

Secara historis, Indonesia memiliki catatan sebagai salah satu negara pengekspor minyak bumi terbesar di dunia, yang tergabung dalam organisasi dunia pengekspor minyak bumi atau Organization of the Petroleum Exporting Countries (OPEC). Indonesia tercatat aktif sebagai negara pengekspor minyak bumi dari tahun 1962 hingga tahun 2009, dan sejak tahun 2009, Indonesia mengalami defisit kebutuhan minyak bumi dalam negeri, sehingga memaksa Indonesia melakukan impor pada tahun tersebut hingga saat ini. Secara volume, kebutuhan minyak bumi mengalami defisit per tahun 2003, namun baru pada tahun 2012, Indonesia mengalami defisit anggaran dalam pemenuhan minyak bumi. Indonesia meninggalkan OPEC pada tahun 2009, dikarenakan statusnya sebagai net exporter of oil, tetapi tidak mampu memenuhi kebutuhan dalam negerinya, dimana pertumbuhan permintaan lebih besar daripada suplainya (BBC News, 2008 in Wikipedia). Istilah ini dikemukakan sebagai "dari net exporter menjadi net importer". Hal inilah yang menjadikan Indonesia menjadi
Ganjar Samudro

Konservasi Energi Berbasis Renewable Energy Technology

salah satu negara yang mengalami krisis energi dari sektor migas. Oleh karena itu, langkah-langkah adaptif dan tindakan perlu dilakukan secara tepat, agar krisis energi ini dapat segera diatasi dengan penggunaan dari berbagai alternatif penyuplai energi.

Kebutuhan energi Indonesia ditopang oleh sektor migas, khususnya minyak bumi, batubara dan gas alam. Kilang minyak bumi menghasilkan beberapa produk seperti bensin (pertamax dan premium) dan solar (pertadex dan biosolar), yang banyak dipergunakan sebagai bahan bakar utama aktivitas kendaraan, domestik dan nondomestik. Sedangkan batubara, banyak dipergunakan sebagai bahan bakar utama dalam pembangkit listrik. Selain minyak bumi dan batubara, gas alam juga banyak dipergunakan sebagai bahan bakar utama domestik dan non-domestik, serta sebagian untuk transportasi. Berdasarkan supply and demand minyak bumi, batubara dan gas alam, supply batubara dan gas alam masih lebih besar dibandingkan demand. Hal ini dikarenakan fungsi batubara dan gas alam seperti contoh yang tersebut diatas. Oleh karena itu, saat ini Indonesia menjadi salah satu negara pengekspor batubara dan gas alam terbesar di dunia.

Penggunaan bahan bakar dari minyak bumi, batubara dan gas alam menghasilkan emisi gas buang berupa karbondioksida $\left(\mathrm{CO}_{2}\right)$, karbonmonooksida (CO), sulfit/sulfur oksida (SOx), nitrogen oksida (NOx), dan sejumlah unsur atau senyawa lain berupa logam berat lainnya. Perhatian parameter utama sebagai indikator pencemar khususnya penyebab global warming adalah karbondioksida $\left(\mathrm{CO}_{2}\right)$. Karbondioksida terperangkap dalam atmosfer bumi, yang menyebabkan radiasi matahari terjerap, sehingga memunculkan fenomena smog atau lapisan/layer yang terdiri dari gabungan asap dan kabut (asbut) yang mengandung karbondioksida $\left(\mathrm{CO}_{2}\right)$ dan pencemar-pencemar lainnya.

\section{HUBUNGAN KONSUMSI ENERGI DENGAN EMISI KARBONDIOKSIDA}

Menurut sumber dari U.S. Energy Information Administration, International Energy Statistics (2011) mengenai Energy Profile of Indonesia yang diakses pada http://www.eoearth.org/view/article/152501, didapatkan informasi mengenai sumbersumber energi Indonesia, yang terdiri dari 
petroleum/minyak bumi dengan proporsi penggunaan sebesar $30 \%$, coal/batubara sebesar 22\%, biomass \& renewable sebesar 29\% dan natural gas sebesar 19\%. Bersumber dari Administration, E. tahun 2013 mengenai energy profile of Indonesia, didapatkan nilai $2.10^{15}$ BTU dari penggunaan biomass \& renewable, maka nilai satuan BTU untuk masing-masing sumber energi dapat dihitung dan dikonversi menjadi satuan kWh, kemudian satuan kWh dihitung dan dikonversi menjadi satuan ton $\mathrm{CO}_{2}$. Sehingga total ton $\mathrm{CO}_{2}$ yang dihasilkan dari penggunaan energi di Indonesia sebesar 559.244.812,5 ton $\mathrm{CO}_{2}$ terhitung pada tahun 2011. Kalkulasi besaran konversi kWh ke ton $\mathrm{CO}_{2}$ menggunakan referensi dari Defra Department of Environment and Climate Change (DECC) guidelines tahun 2012.

Kontribusi Indonesia terhadap emisi karbondioksida terbilang cukup besar, karena mencapai peringkat ketiga bersama Australia, Timur Tengah, sebagian Asia Timur, sebagian Eropa, Afrika Selatan, Amerika Serikat dan Kanada. Secara kuantitatif, nilai kontribusi Indonesia terhadap emisi karbondioksida sebesar
2,32 ton $\mathrm{CO}_{2} /$ jiwa dengan perbandingan masih lebih kecil dibandingkan kontribusi dunia terhadap emisi karbondioksida sebesar 4,9 ton $\mathrm{CO}_{2} /$ jiwa. Apabila nilai emisi karbondioksida tersebut dikonversi ke satuan ${ }^{\circ} \mathrm{C}$, dengan asumsi dasar 1 ton $\mathrm{CO}_{2}$, meningkatkan suhu sebesar $0,0000000000015{ }^{\circ} \mathrm{C}$, maka nilai suhu dapat diperkirakan sebesar $0,00084{ }^{\circ} \mathrm{C}$, yang merupakan kontribusi Indonesia terhadap kenaikan suhu global dunia. Nilai suhu tersebut sangatlah kecil, tetapi Indonesia telah merasakan dampakdampak negatif dari perubahan suhu tersebut. Oleh karena itu, Indonesia tetap harus memiliki strategi menurunkan emisi karbondioksida per kapita, sebagai kontribusi terhadap penyelamatan lingkungan dunia dari dampak global warming.

Secara global, kenaikan suhu dapat diprediksi hingga mencapai sebesar $1{ }^{\circ} \mathrm{C}$ pada tahun 2040, dengan nilai kontribusi Indonesia terhadap kenaikan suhu global sebesar $0,024{ }^{\circ} \mathrm{C}$. Nilai tersebut terhitung besar dan dapat diprediksi dampak-dampak negatif dari perubahan suhu tersebut ke depannya.

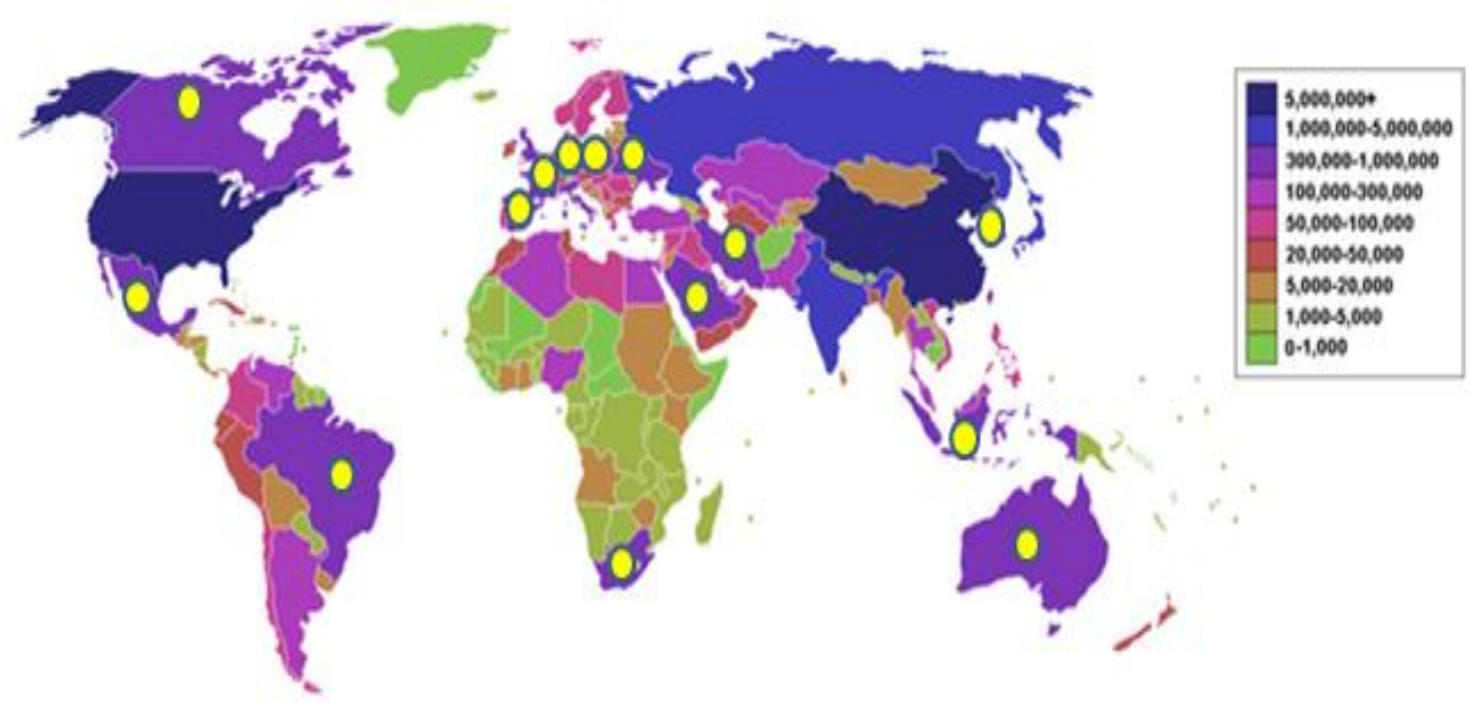

Gambar 1. Pemetaan Emisi $\mathrm{CO}_{2}$ Dunia

\section{TEKNOLOGI ENERGI TERBARUKAN}

Dalam rangka menciptakan teknologiteknologi penghasil energi ramah lingkungan dan dapat diperbaharui, maka perlu diketahui jenis-jenis teknologi yang telah dikembangkan saat ini, meliputi pembuatan bio-etanol dan bio-solar melalui proses fermentasi dan lanjutannya, biodigester yang menghasilkan biogas, pupuk cair dan kompos, destilasi bertingkat yang merubah plastik menjadi premium dan minyak tanah, dan lain sebagainya.

Secara umum, renewable energy technologies terdiri dari solar energy 
dengan teknologi solar cell/sel surya, hydropower energy dengan teknologi turbin air pembangkit listrik baik air yang berasal dari laut maupun air permukaan, geothermal energy dengan teknologi geothermal power plant, wind energy dengan teknologi wind turbine/turbin kincir angin dan biomass energy dengan teknologi konversi biomassa. Masingmasing teknologi yang bersumber dari alam ini memiliki kelebihan dan kekurangan, namun secara prinsip bahwa teknologi dari alam ini lebih ramah lingkungan yang sekaligus menjadi salah satu kelebihannya, sedangkan kekurangan utamanya terletak pada biaya investasi dan OM yang masih tergolong tinggi. Oleh karena itu, perkembangan teknologi saat ini telah meluas pemanfaatannya, khususnya energi yang bersumber dari biomassa. Teknologi konversi biomassa ini dapat menjadi mahal investasi dan OM-nya, apabila tidak diketahui teknik atau cara atau metode tepat dalam pengoperasian dan pemeliharaannya. Kompetisi dalam pengembangan teknologi konversi biomassa ini semakin banyak akhir-akhir ini, walaupun cenderung melambat seiring stagnasi perkembangan dan pemanfaatan teknologi yang ada.

Sumber-sumber biomassa yang sangat melimpah di dunia ini, menjadi tolok ukur pengembangan teknologi konversi biomassa. Salah satunya adalah biomassa dari mikroorganisme, yang sekaligus memiliki 2 (dua) fungsi utama, yaitu sebagai bahan organik itu sendiri dan bioreaktor pemroses bahan organik menjadi energi. Fungsi mikroorganisme sebagai bioreaktor pemroses bahan organik menjadi energi ini menjadi fokus pengembangan, karena secara siklus rantai makanan, mikroorganisme merupakan kelompok tersendiri sebagai decomposer dari kelompok lainnya seperti tumbuhan sebagai produsen dan hewan sebagai konsumen. Pengertiannya bahwa mikroorganisme sebenarnya dapat memiliki tiga fungsi kehidupan, yaitu sebagai coprodusen, konsumen dan decomposer.

\section{TEKNOLOGI MICROBIAL}

\section{Konvensional}

Pembangkit energi dengan teknologi microbial konvensional yang berkembang saat ini, terdiri dari an-aerobik digester, gasifier dan pyrolysis, yang memanfaatkan bahan-bahan organik, seperti kelapa sawit, kelapa, jarak pagar, kapas, kanola, dan rapeseed untuk biodiesel, serta ubi kayu, ubi jalar, tebu, sorgum, sagu, aren, nipah, dan lontar untuk bioetanol (Sumaryono, 2006), kotoran ternak, kotoran manusia, sampah organik dan an-organik, lumpur, limbah cair dan padat, serta ligniselulosa/selulosa. Produk yang dihasilkan dapat berupa bio-diesel/biosolar, bio-etanol, biogas dan bio-minyak tanah. Teknologi microbial konvensional ini sangat tepat untuk diterapkan pada negaranegara berkembang, seperti Indonesia, namun keterbatasan teknis dan non-teknis, pemanfaatannya belum meluas. Oleh karena itu diperlukan metode tambahan untuk meningkatkan nilai jual teknologi microbial konvensional ini.

\section{Lanjutan (Advanced)}

Selain teknologi microbial konvensional, pembangkit energi dengan teknologi microbial lanjutan/advanced sedang terus dikembangkan untuk mendapatkan energi ramah lingkungan dan pemanfaatannya meluas, serta dapat diterapkan pada segala kondisi. Teknologi microbial lanjutan atau teknologi microbial masa depan, diantaranya adalah Microbial Fuel Cells (MFCs) dengan turunanturunannya (seperti Soil-based MFCs, Plant MFCs, Microbial Solar Cells, dan Phototrophic Biofilm MFCs), Microbial Electrolysis Cells (MECs), dan Microbial Electrosynthesis Cells (MECs), serta perkembangan modifikasi MFCs lainnya.

Teknologi microbial lanjutan, seperti MFCs ini merupakan pengembangan dari teknologi Fuel Cells. Perbedaannya terletak pada proses konversi atau transformasi, dimana MFCs mengkonversi atau mentransformasi proses biokimia menjadi biolistrik. MFCs merupakan adopsi tubuh mikroorganisme, dimana proses-proses metabolisme, seperti reaksi oksidasi reduksi, transfer elektron dan proton terjadi secara kontinyu.

Teknologi MFC menggambarkan pendekatan terbaru dalam hal penghasilan energi listrik. Energi listrik dalam MFC dihasilkan melalui reaksi biologis oleh bakteri. Dalam MFC, mikroorganisme mendegradasi material organik, memproduksi elektron melalui reaksi enzimatis dalam sel dan menghasilkan energi untuk sel tersebut dalam bentuk 
ATP. Elektron-elektron kemudian dilepaskan menuju terminal electron acceptor (TEA) yang menerima elektron sehingga mengalami reduksi (Logan, 2008).

MFCs harus dikembangkan untuk aplikasi di daerah yang kemungkinan akan menghasilkan keuntungan terbesar. MFC dapat diaplikasikan secara luas sehingga dapat menjadi metode pemulihan energi untuk membuat infrastruktur air yang berkelanjutan. MFC merupakan teknologi yang menjanjikan untuk pengolahan air limbah sehingga dapat menghasilkan energi dalam bentuk listrik atau gas hidrogen (Logan, 2008).

\section{KAJIAN OPERASIONAL DAN BIAYA}

Menurut Pham dkk, (2006), rule of thumb dari $1 \mathrm{~kg}$ glukosa dapat dikonversi menjadi $1,06 \mathrm{~kg}$ COD, 4,41 kWh, $13.10^{6}$ coulomb, 0,5 Liter etanol, 1,2 $\mathrm{m}^{3}$ hidrogen, $0,36 \mathrm{~m}^{3}$ gas methan dan 0,5 Liter biogas. Rule of thumb ini dipergunakan sebagai dasar perhitungan perencanaan, operasi dan pembiayaan teknologi konversi biomassa, serta konservasi energi. Seperti diketahui bahwa suatu teknologi konversi biomassa tidak dapat mengkonversi dan menghasilkan produk sesuai rule of thumb tersebut diatas, oleh karena itu konservasi energi perlu menjadi perhatian untuk optimalisasi proses.

Ketidakefisienan teknologi konversi biomassa, seperti pada reaktor an-aerobik digester, dapat dilihat pada bagian heat exchanger dan genset methan. Hal ini sama halnya pada pembangkit listrik, losses/kehilangan energi muncul pada bagian produksi, transmisi dan distribusi listrik ke konsumen. Kehilangan energi memberikan dampak pada lingkungan, khususnya meningkatnya emisi gas $\mathrm{CO}_{2}$ ke atmosfer. Oleh karena itu, bagian-bagian tersebut perlu inovasi tambahan untuk meningkatkan produksi energi dalam upaya konservasi energi.

Contoh lain dalam penggunaan energi di Instalasi Pengolahan Air Limbah (IPAL), dimana penggunaan energi listrik ataupun Bahan Bakar Minyak (BBM) menyebabkan kehilangan energi dengan perkiraan sebesar 0,32 kWh/m $\mathrm{m}^{3}$ (Water Environment Federation, 2009 dalam Shun'ichi Ishii et al., 2013) - 0,47 kWh/m $\mathrm{m}^{3}$ (Setiyono, 2009), yang dikonversi menjadi emisi $\mathrm{CO}_{2}$ sebesar $0,05-0,08 \mathrm{~kg} / \mathrm{m}^{3}$. Pengertiannya setiap 1 $\mathrm{m}^{3}$ air limbah yang diproses dalam IPAL, menyumbang 0,05 - 0,08 kg $\mathrm{CO}_{2}$ yang dilepaskan ke atmosfer. Oleh karena itu efisiensi proses dalam suatu instalasi juga perlu diperhatikan untuk menghemat pelepasan energi yang besar. Semakin besar energi yang dilepaskan atau kehilangan energi, maka semakin besar pula kontribusi emisi $\mathrm{CO}_{2}$ ke atmosfer.

Salah satu solusi inovasi teknologi konversi biomassa adalah rancang kombinasi reaktor an-aerobik digester dengan MFCs, sebagaimana rancangan oleh Pham dkk, (2006), dimana terdapat 2 (dua) tipe, yaitu kombinasi reaktor anaerobik digester dengan MFCs yang digabung dalam 1 (satu) reaktor dan reaktor seri yang diawali dari reaktor anaerobik digester, kemudian lanjut ke reaktor MFCs. Berdasarkan kajian biaya operasional yang dilakukan, didapatkan bahwa reaktor seri merupakan pilihan yang terbaik, dimana capture energi besar, kebutuhan energi nol, revenue listrik tinggi dan biaya operasional yang rendah. Pilihan inovasi teknologi ini membuka wacana pengembangan inovasi teknologi microbial lainnya dan memberikan kontribusi pengurangan emisi $\mathrm{CO}_{2}$ dari suatu proses.

\section{HASIL-HASIL PENELITIAN}

Penelitian dengan obyek MFCs telah banyak dilakukan, yang tercatat dalam indexing elsevier sciencedirect sejak tahun 2001 hingga sekarang, begitu juga pada tahun-tahun sebelumnya yang dimulai sejak periode akhir tahun 1990-an, terdapat penelitian serupa, namun belum spesifik.

Bruce E. Logan dari Universitas Pennsylvania USA beserta rekan-rekan meneliti aktif sejak tahun 2006 hingga sekarang dan menciptakan banyak inovasiinovasi terkait pengembangan MFCs. Secara aplikasi, MFCs sebenarnya sangat memungkinkan dikembangkan di negaranegara berkembang, seperti Indonesia, dikarenakan kemampuan kinerjanya dapat dimanfaatkan untuk menyelesaikan masalah-masalah lingkungan dan sekaligus menghasilkan energi listrik yang berguna bagi daerah-daerah terpencil dan jauh dari jaringan listrik.

Penelitian MFCs di Indonesia masih sangat jarang jumlahnya, terutama publikasi ilmiah internasional dalam skala fundamental maupun pengembangannya, sehingga penelitian ini sangat mendesak 
dilakukan, mengingat negara-negara asia timur dan selatan telah banyak mengembangkan penelitian ini hingga siap diaplikasikan dalam skala besar. Penelitian MFCs yang telah ada di Indonesia dimulai sejak tahun 2009 hingga sekarang dengan skala ideal menggunakan medium organik (enrichment medium) dan beberapa telah dikembangkan menggunakan limbah cair.

Secara sistematis, kinerja MFC tentu dapat diterapkan dalam sebuah sistem pengolahan limbah cair. MFC dapat diterapkan sebagai salah satu treatment dalam pengolahan limbah dengan memasukkannya sebagai pengganti dari proses activated sludge maupun trickling filter. Namun disisi lain MFC juga dapat ditawarkan sebagai pretreatment untuk proses MBR atau membran bioreaktor, mengingat bahwa sistem MFC belum pernah dicobakan dalam skala yang besar. MFC adalah proses pengolahan biologis, memiliki fungsi yang sama dengan kedua tahap tersebut. Ada empat keuntungan utama menggunakan MFC diantaranya: (1) menghasilkan listrik pada MFC maupun gas hidrogen pada MEC sehingga memiliki multi fungsi, (2) mengurangi kebutuhan untuk aerasi. Aerasi di AS dapat mengkonsumsi $50 \%$ dari listrik pabrik pengolahan. Namun pada MFC tidak diperlukan aerasi, (3) mengurangi produksi zat padat. MFC adalah proses anaerobik, dan dengan demikian bakteri produksi biomassa akan berkurang dibandingkan dengan sistem aerobik seperti pengolahan sebelumnya, dan (4) potensi untuk kontrol bau. Dalam sistem MFC maupun MEC tidak akan memproduksi bau karena sistem dirancang secara tertutup sehingga gangguan bau dapat dihindarkan (Logan, 2008).

Salah satu pengembangan penelitian MFCs di Indonesia dengan medium organik dari limbah cair dilakukan oleh Samudro dkk, (2014) yang dipublikasikan pada Prosiding Seminar Nasional Teknologi Industri Hijau Kota Semarang, dimana reaktor disusun dengan 2 (dua) chamber anoda dan katoda, elektroda pada chamber berupa lempeng grafit, jembatan garam berupa agar pro-analysis dengan perlakuan

\section{Ganjar Samudro}

Konservasi Energi Berbasis Renewable Energy Technology

penambahan larutan garam $\mathrm{NaCl} 1 \mathrm{M}$, dan limbah cair yang digunakan berasal dari Rumah Pemotongan Hewan (RPH). Hasil penelitian yang didapatkan adalah energi listrik sebesar $17,72 \mathrm{~mW} / \mathrm{m}^{2}$ lebih kecil dari penelitian oleh Liu dkk, (2004) dengan energi listrik sebesar $26 \mathrm{~mW} / \mathrm{m}^{2}$, namun memiliki kelebihan peningkatan efisiensi reduksi COD yang lebih optimal. Sedangkan penelitian yang dilakukan oleh Park dan Zeikus (2002) didapatkan hasil power density sebesar maksimum 10,2 $\mathrm{mW} / \mathrm{m}^{2}$ (efisiensi coulomb dari $4 \%$ ) menggunakan Shewanella putrefacians dan Mn4'-grafit elektroda dan udara-katoda menggunakan laktat sebagai substrat, dan $9,4 \mathrm{~mW} / \mathrm{m}^{2}$ dengan piruvat. Sedangkan penggunaan asetat dan glukosa menghasilkan sebesar 1,6 dan $1,9 \mathrm{~mW} / \mathrm{m}^{2}$. Kerugian tegangan (Voltage losses) akibat metabolisme bakteri sejatinya tidak dapat dihindari karena hal tersebut merupakan konsekuensi dari terlaksananya sebuah reakti dalam rangka bakteri mendegradasi substrat. Pada prinsipnya, bakteri membutuhkan energi yang cukup hanya untuk memompa satu proton melintasi membran dengan menggunakan suatu siklus tertentu. Sehingga diperlukan suatu daya untuk menjadikan sebuah reaksi terjadi (Logan, 2008).

Pengembangan penelitian selanjutnya dilakukan dengan modifikasi beberapa faktor-faktor berpengaruh seperti pengaturan $\mathrm{pH}$ dan penambahan Humic Acid (HA) dengan menggunakan limbah domestik artifisial, didapatkan hasil yang lebih baik, yaitu produksi energi listrik mencapai range $570-737 \mathrm{~mW} / \mathrm{m}^{2}$ lebih besar dari penelitian sebelumnya baik oleh Samudro, dkk (2014) dan Liu et.al. (2004), namun perbedaannya terletak pada limbah cair yang digunakan pada penelitian skala laboratorium. Pengertiannya adalah faktorfaktor berpengaruh tersebut dapat diteliti lebih lanjut terhadap limbah cair actual sebagai perbandingan hasil dengan penelitian sebelumnya. Sebagai analisis awal bahwa faktor-faktor pengganggu lainnya yang berada pada limbah cair actual berpengaruh terhadap produksi energi listrik. 


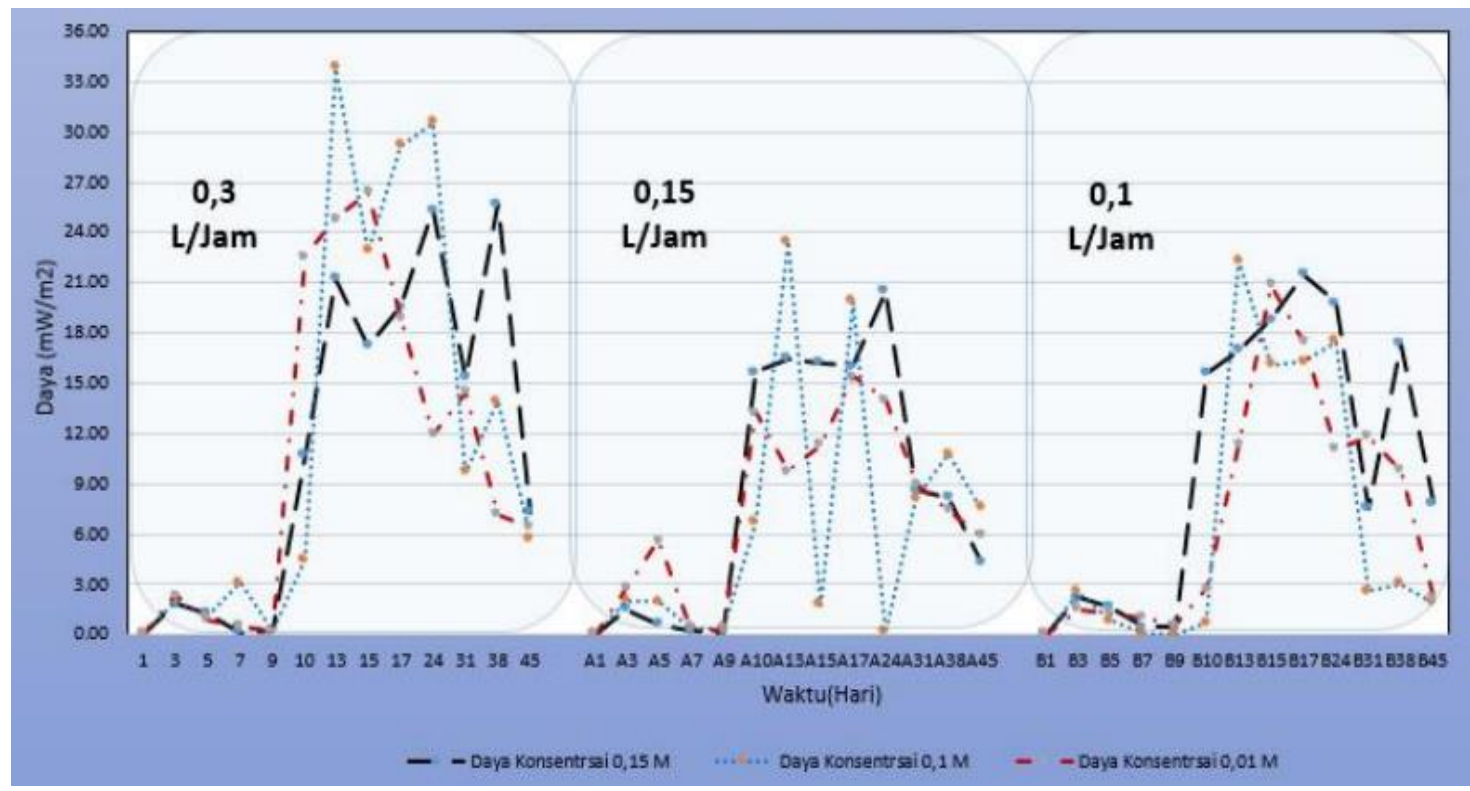

Gambar 2. Perbandingan Produksi Listrik dengan Variasi Debit dan Molaritas Elektrolit

Pada Gambar 2 dapat dilihat bahwa variasi debit $0,3 \mathrm{~L} / \mathrm{Jam}$ dan Konsentrasi $0,15 \mathrm{M} \mathrm{KMnO4}$ adalah variasi dengan hasil produksi listrik yang optimum. Selain itu, variasi debit 0,1 L/Jam merupakan variasi debit optimum dalam mendegradasi kandungan COD didalam air limbah RPH dengan sistem Microbial Fuel Cells dan efisiensi sebesar $89 \%$ (Samudro dkk, 2014).

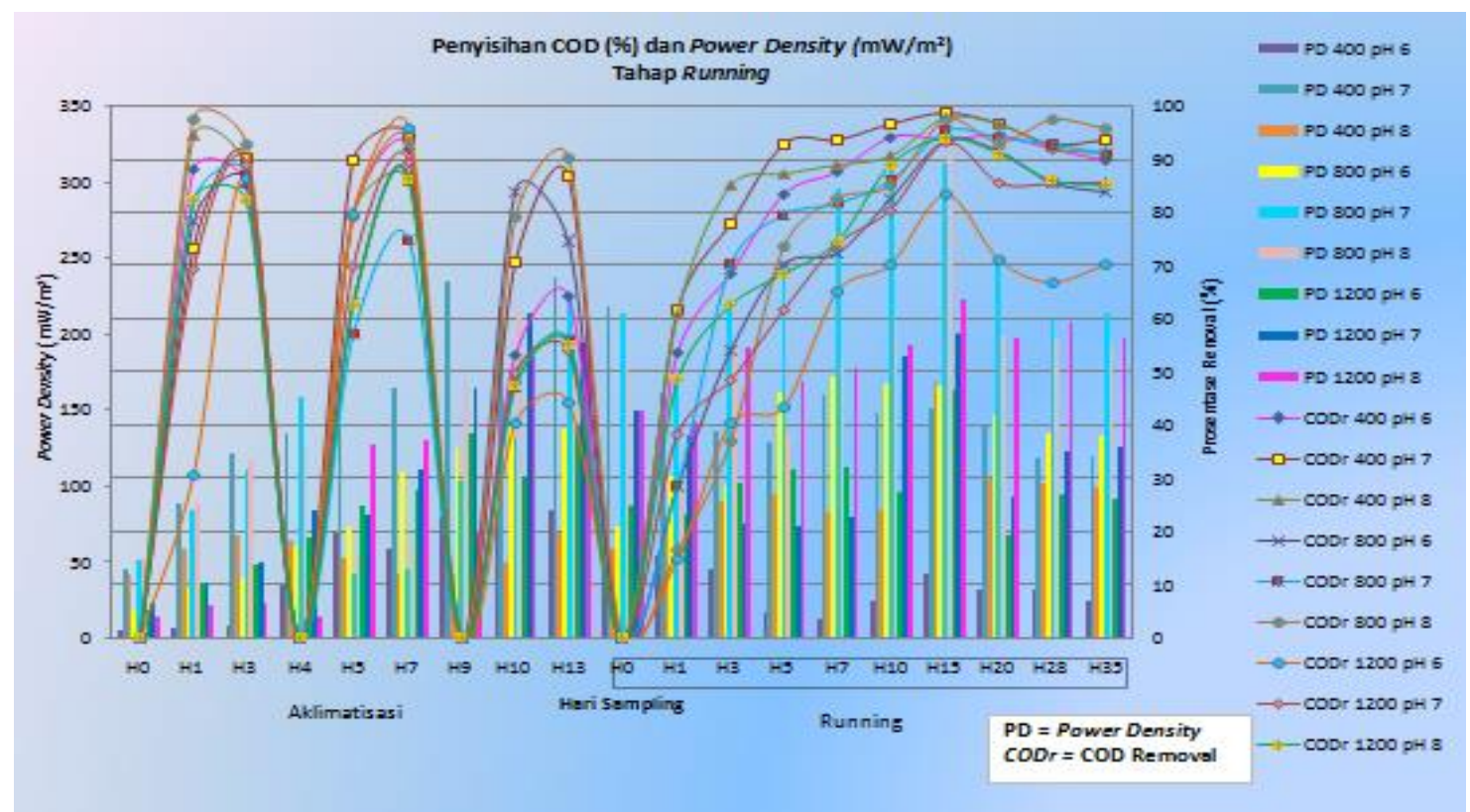

Gambar 3. Perbandingan Produksi Listrik dengan Variasi COD dan pH

Dari Gambar 3 dapat dijelaskan bahwa pada proses running terjadi peningkatan efisiensi penurunan COD pada setiap variasi reaktor. Sampai pada hari ke-5 dan 7 terjadi penurunan efisiensi yang kurang signifikan dikarenakan shock loading untuk kemudian berangsur meningkat kembali. Sampai dengan hari ke-14, perubahan efisiensi sudah tidak signifikan atau mulai stabil. 
Semakin tinggi konsentrasi COD, debit operasional, molaritas elektrolit $\mathrm{KMnO} 4$ 0,1 $\mathrm{M}$, serta $\mathrm{pH}$ 8, maka semakin tinggi dan stabil produksi energi listrik. Hal tersebut ditunjang kemudian dengan hasil penelitian lanjutan dengan beberapa modifikasi faktorfaktor berpengaruh. Beberapa hasil yang didapatkan, yaitu (1) semakin besar konsentrasi dan debit aliran dengan rasio substrat-nutrisi C:N:P sebesar 100:10:1, serta $\mathrm{pH}$ 8, maka semakin besar produksi listrik dan penurunan COD, (2) Semakin besar konsentrasi dan debit aliran dengan rasio substrat-nutrisi $\mathrm{C}: \mathrm{N}: \mathrm{P}$ sebesar 100:10:1, serta $\mathrm{pH}$ 8, serta jembatan garam yang ditambahkan $1 \mathrm{M} \mathrm{NaCl}$, maka semakin besar produksi listrik dan penurunan COD, (3) Semakin besar konsentrasi dan debit aliran dengan rasio substrat-nutrisi C:N:P sebesar 100:10:1, serta $\mathrm{pH} 8$, serta luas elektroda $25 \mathrm{~cm}^{2}$, maka semakin besar produksi listrik dan penurunan COD, (4) Penambahan humic acid sebagai mediator dan ragi sebagai katalisator, meningkatkan penurunan COD, namun menyebabkan penurunan produksi listrik, dan (5) Penambahan Granular Activated Carbon (GAC) sebagai media terlekat, meningkatkan produksi listrik dan penurunan COD. Karakterisasi yang mendalam pada reaktor dan solusi-solusi kimia diperlukan untuk lebih memahami dan meningkatkan kinerja MFC. Potensi redoks dalam reaktor selama degradasi substrat, serta perubahan $\mathrm{pH}$ lokal di sekitar dan dalam biofilm yang tumbuh pada kedua elektroda maupun membran jika ada, sebisa mungkin dipantau (Logan, 2008). Operasional MFCs yang diaplikasikan dalam pengolahan limbah cair dipengaruhi oleh beberapa faktor, seperti substrat, sifat kimia larutan, temperatur, hydraulic retention time (HRT), konfigurasi reaktor, dan jenis reactor (Samudro dkk, 2014).

\section{KESIMPULAN DAN SARAN}

a. Konservasi energi tidak hanya terfokus pada efisiensi energi, namun sangat mendesak untuk pengembangan inovasi teknologi ramah lingkungan berbasis renewable energy.

b. Salah satu renewable energy technology dengan pemanfaatan MFCs dan sejenisnya perlu dikembangkan secara single reactor maupun dual reactor dengan kombinasi AD-MFCs untuk mendapatkan manfaat gas methan, listrik, air dan hidrogen.

c. Teknologi produksi listrik dengan pemanfaatan MFCs belum benar-benar 'matang' dan siap dilakukan dalam skala besar. Teknologi ini akan terus diteliti dan dikembangkan untuk mencukupi kebutuhan energi baru dan terbarukan, serta ramah lingkungan.

\section{UCAPAN TERIMA KASIH}

Ucapan terima kasih disampaikan kepada Program Studi Teknik Lingkungan Fakultas Teknik Universitas Diponegoro Semarang dan Prodi Teknik Lingkungan Universitas Lambung Mangkurat Banjarmasin.

\section{DAFTAR PUSTAKA}

BBC News. 2008. Indonesia to Withdraw from OPEC. Wikipedia: akses http://news.bbc.co.uk/2/hi/7423008.stm

Defra. 2012. 2012 Guidelines to Defra / DECC"s GHG Conversion Factors for Company Reporting: Methodology Paper for Emission Factors. Department for Environment, Food and Rural Affairs. London. Pages 74

Langdon D. Clough.. 2011. Energy Profile of Indonesia. U.S. Energy Information Administration, International Energy Statistics Akses http://www.eoearth.org/view/article/152 $\underline{501}$

Liu, H., Ramnarayanan, R. and Logan, B.E. 2004. Production of electricity during wastewater treatment using a single chamber microbial fuel cell. Environ. Sci. Technol. 38(7), 2281-2285

Logan, Bruce E. 2008. Microbial Fuel Cells. WILEY-INTERSCIENCE. John Wiley \& Sons, Inc.

Park, D.H. and Zeikus, J.G. 2002. Impact of electrode composition on electricity generation in a single-copartment fuel cell using Shewanella putrefucians. Appl. Microbiol. Biotechnol. 59, 58-61.

Samudro, G., Hadiwidodo, M. dan Ardhianto, R. 2014. Pemanfaatan Microbial Fuel Cells (MFCs) dalam Produksi Energi Listrik: Studi Variabel Debit Input dan Konsentrasi Elektrolit $\mathrm{KMnO}_{4}$. Prosiding Semnas Teknologi Industri Hijau Semarang: BBTPPI

Setiyono. 2009. Disain Perencanaan Instalasi Pengolahan Air Limbah 
(IPAL) dan Re-Use Air di Lingkungan Perhotelan. JAI Vol 5. No. 22009

Sumaryono. 2006. Potensi Sumber Daya Lahan dan Optimalisasi Pengembangan Komoditas Penghasil Bioenergi di Indonesia. Akses http://www.academia.edu/10064498/P OTENSI SUMBER DAYA LAHAN D AN OPTIMALISASI PENGEMBANGA N KOMODITAS PENGHASIL BIOEN ERGI DI INDONESIA

Shun'ichi Ishii, Shino Suzuki, Trina M. Norden-Krichmar, Angela Wu, Yuko Yamanaka, Kenneth $\mathrm{H}$. Nealson, and
Orianna Bretschger. 2013. Identifying the Microbial Communities and Operational Conditions for Optimized Wastewater Treatment in Microbial Fuel Cells. Water Research, 4, 71207130

T. H. Pham, K. Rabaey, P. Aelterman, P. Clauwaert, L. De Schamphelaire, N. Boon, and W. Verstraete. 2006. Microbial Fuel Cells in Relation to Conventional Anaerobic Digestion Technology. WILEY-VCH Verlag $\mathrm{GmbH} \&$ Co. KGaA, Weinheim. Eng. Life Sci. 2006, 6, No. 3 